\title{
THE BORDERLINE PERSONALITY DISORDER OF ANTONY IN THE DRAMA ANTONY AND CLEOPATRABY WILLIAM SHAKESPEARE
}

\author{
Eny Suprihandani \\ Thea Jacinda
}

\begin{abstract}
Literature can be analyzed from many perspectives and point of views. By using psychoanalytic approach, this paper attempts to analyze one of the Shakespearean's characters, Antony in the drama Antony and Cleopatra. The objective is to prove whether Antony truly suffers from Borderline Personality Disorder. Borderline Personality Disorder (BPD) is a personality disorder whose essential features are a pattern of marked impulsivity and instability of affects, interpersonal relationships, and self-image. Psychoanalysis theory is a theory developed by Sigmund Freud that enables to analyze whether a person suffers from a certain mental disease. Using those approaches, the characterization of Antony can be analyzed from his words, thoughts and other character's opinion about him and then compared to the symptoms of Borderline Personality Disorder (BPD) and then found if they are matched. That Antony suffers from Borderline Personality Disorder can be finally proved.
\end{abstract}

Keywords: psychoanalytic approach, Borderline Personality Disorder

\section{A. INTRODUCTION}

\section{Background}

Drama is one of the classical literary works that are intended to be performed upon the stage. For those who like literary works but do not like to read, drama is a perfect way to enjoy literary works without reading it. Drama comprises speech, movement, design, and or music that make it more enjoyable and attractive. Drama can reflect and affect people who watch it, especially for those who like literary works. It has evolved over the decades, through time and space.

There are various kinds of drama, such as tragedy, comedy, and romance. It has developed in many variations throughout the decades. Tragedy usually tells about downfall, denials, betrayal, and ends with unhappy ending story. Tragedy, mostly round about well-known epic, historical, and or mythological stories, commonly presents a serious theme where mostly the hero accept the 
responsibilities of his actions and willingly suffer and sacrifice. Tragedy is considered to be the greatest theme because it was mostly written during the greatest period of drama.

Antony and Cleopatra is a tragedy by William Shakespeare. It was written between 1606-1607 in London, England. The Play sets in Egypt, Alexandria and Rome, Italy. The play tells about the affair of the Roman general Antony and the Egyptian queen Cleopatra, and the quarrel between Antony and Octavius Caesar. Their blind passion leads to their ultimate downfall and deaths. The plot focuses on themes of ambition, power, love, friendship, deception, and disaster.

Antony and Cleopatra can be analyzed from many perspectives. For example, commentators have puzzled for centuries about Antony's behavior, thoughts, and relationship. His loyalty is divided between the Western and Eastern worlds and torn between duties and pleasures. Some see it as a playground plot a plot of device to prolong the action, and others see it as the result of pressure exerted by the complex philosophical and ethical issues. More recently, psychoanalytic critics have examined Antony's personality disorder.

The psychoanalytic theory will give much information and lead in finding Antony's inappropriate behavior and thoughts. This paper focuses on finding much information related to his borderline personality disorder, which can be seen through his activities, thoughts and self-concept as described explicitly in the drama.

\section{Objectives}

The objectives of this research are (1) to know Antony's character; (2) to find out the Antony's conflicts that influence his characters; and (3) to know the evidence that shows Antony's Borderline personality disorder.

\section{Theoretical Framework}

\subsection{Character}

Lexically character means the mental or moral qualities that make a chief person different from other. (Hornby: 1974) Another definition of character is the 
principal person or leading person in drama or novel who marks distinctive qualities which make up the person's personality in the part. (Webster: 1993)

Literally character means a person presented in a dramatic or narrative work, and characterization is the process by which a writer makes that character seem real to the reader. A character can also be defined as any person, persona, identity, or entity that exists in a work of art. Along with plot, setting, theme, and style, character is considered one of the fundamental components of fiction. (Obstfeld. 2002) From the lexical and literal definition above, character can be defined as the person in fiction or narrative works with several qualities that are different with other person.

\subsection{Classification of Character}

a. Round VS Flat

Round characters are so detailed that they seem real. Protagonists are normally round characters, though notable exceptions exist. Round characters are more complex than flat or stock characters, and often display the inconsistencies and internal conflict found in most real people. They are more fully developed, and therefore are harder to summarize. Antagonists are often rounds as well, though comedic villains may be almost farcically flat. A flat character is distinguished by its lack of detail. However, the description of a flat character may be detail and usually just follows one characteristic. A flat character embodies one or two qualities, ideas, or traits that can be readily described in a brief summary. They are not psychologically complex characters and therefore are readily accessible to readers. Supporting Characters are generally flat, as more minor roles do not require a great deal of complexity. In addition, experimental literature and postmodern fiction often intentionally make use of flat characters, even as protagonists.

b. Dynamic VS Static

A dynamic character is the one who changes significantly during the course of the story. Changes considered to qualify a character as dynamic include changes in insight or understanding, changes in commitment, Changes in circumstance, even physical circumstance, do not apply unless they result in some change within the character's self. By definition, the protagonist is nearly 
always a dynamic character. In coming-of-age stories in particular, the protagonist often undergoes dramatic change, transforming from innocence to experience. In contrast, a static character does not undergo significant change. Whether round or flat, their personalities remain essentially stable throughout the course of the story. This is commonly done with secondary character does not change throughout the work, and the reader's knowledge of that character does not grow, whereas a dynamic character undergoes some kind of change because of the action in the plot.

C. A non-fictional character

A non-fictional character is a character that actually exists or existed in history, though their exploits in the story may differ from their historical activities.

\subsection{Conflict}

\section{1) Definition of Conflict}

Lexically conflict is defined as a state of open, often prolonged fighting, a battle, or war and a state of disharmony between incompatible or antithetical persons, ideas, or interests. (The American Heritage ${ }^{\circledR}$ Dictionary of English Language: 2003) The definition of conflict in Webster Dictionary also means the quarrel between two or more people or community. The definitions are given as follows:

a. Fight, battle, war

b. Competitive or opposing action of incompatibles : antagonistic state or action (as of divergent ideas, interests, or persons)

c. Mental struggle resulting from incompatible or opposing needs, drives, wishes, or external demands

d. The opposition of persons or forces that gives rise to the dramatic action in a drama or fiction

Literally conflict means opposition between characters or forces in a workof drama or fiction, especially opposition that motivates or shapes the action of the 
plot. Conflict is essential to plot. Without conflict, there is no plot. It is the opposition of forces which ties one incident to another and makes the plot move.

In general, conflict can be defined as the struggles or forces happened between opposing characters, could be between two or more characters, which give rise to the dramatic action in the plot of a narrative work.

\section{2) Kinds of Conflict}

Generally, there are two classifications of conflict, which are internal and external conflict. The internal conflict is a struggle within one's self; a person must make some decision, overcome pain, quiet their temper, resist an urge, etc. In order words, internal conflict is the conflict between someone and his own self or mind. External conflict is a struggle with a force outside one's self. Furthermore; there are also four kinds of conflict, which are:

\section{a. Man versus Man}

Conflict that pits one-person against another.

\section{b. Man versus Nature}

A run-in with forces of nature. On the one hand, it expresses the insignificance of a single human life in the cosmic scheme of things. On the other hand, it tests the limits of a person's strength and will to live.

\section{c. Man versus Society}

The values and customs by which everyone else lives are being challenged. The character may come to an untimely end because of his or her convictions. The character may bring others around to a sympathetic point of view, or may decide that society was right after all.

\section{d. Man versus Self (Internal Conflict)}

Not all conflict involves other people. Sometimes people are their own worst enemies. An internal conflict is a good test of a character's values. Does he give in to temptation or rise above it? Does he demand the most from himself or herself or settle for something less? Does he or she even bother to struggle? The internal conflicts of the character and how they are resolved are good clues to the character's inner strength. 
Often, more than one kind of conflict is taking place at the same time. In every case, however, the existence of conflict enhances the reader's understanding of a character and creates the suspense and interest for them.

\section{Borderline Personality Disorder}

\section{1) Definition of Borderline Personality Disorder}

Borderline Personality Disorder is a highly prevalent, chronic, and debilitating psychiatric problem characterized by a pattern of chaotic and selfdefeating interpersonal relationship, emotional liability, poor impulse control, angry outburst, frequent suicidality, and self-mutilation (Skodol, Gunderson, Livesley, Pfohl, Siever, Widiger, 2002). Borderline Personality Disorder is noted with the impulsivity, affective liability, and self-damaging actions. Borderline Personality Disorder in males is sometimes referred to as the Casanova Disorder and it is one of psychiatry's best-kept secrets. Perhaps because the behavior or symptoms in males, which are nearly identical to those in women, are considered more accepted by the culture therefore making it more difficult to recognize and to diagnose. This is that cause of the Borderline Personality Disorder based on the book of psychology DSM-IV. This disorder is believed to originate, at least in part during infancy or early childhood, and involves an abusive or emotionally neglectful mothering or primary caregiver.

The mother may be depressed, distant, or simply disinterested her male child. As an adult the male borderline is searching for the female nurturing and affection which he never received as a boy. This is not to negate the biological or genetic component that also seems to play a role in the development of this disorder.

These are the symptoms of Borderline personality disorder for men:
a. Very romantic
b. Short-lived relationship
c. Mood swings
d. Love addict/love phobic 

e. Narcissistic/insecure
f. Sensitive to criticism
g. Suspicious, untrusting, and jealous
h. Recklessness
i. Low self-esteem
j. Suicidal thoughts

There is no cure for Borderline Personality Disorder. However, with the proper treatment and time, patients can make significant improvements. Like most personality disorders, borderline personality disorder typically will decrease in intensity with age.

\section{2) The Theory of Borderline Personality Disorder}

The concept of Borderline personality disorder was revived by Swiss physician, ThéophileBonet, in 1684 who, using the term foliemaniacomélancolique, described the phenomenon of unstable moods that followed an unpredictable course. Other writers noted the same pattern, including the American psychiatrist C. Hughes in 1884 and J.C. Rosse in 1890, who called the disorder "borderline insanity"

Research on the possible causes and risk factors for BPD is still at a very early stage. However, scientists generally agree that genetic and environmental factors are likely to be involved. Studies on twins with BPD suggest that the illness is strongly inherited. Another study shows that a person can inherit his or her temperament and specific personality traits, particularly impulsiveness and aggression. Scientists are studying genes that help regulate emotions and impulse control for possible links to the disorder.

Social or cultural factors may increase the risk for BPD. For example, being part of a community or culture in which unstable family relationships are common may increase a person's risk for the disorder. Impulsiveness, poor judgment in lifestyle choices, and other consequences of BPD may lead individuals to risky situations.

Most people who have BPD suffer from: 

a. Problems with regulating emotions and thoughts
b. Impulsive and reckless behavior
c. Unstable relationships with other people.

People with this disorder also have high rates of co-occurring disorders, such as depression, anxiety disorders, substance abuse, and eating disorders, along with self-harm, suicidal behaviors, and completed suicides.

\section{The Psychoanalysis Theory}

Psychoanalysis is a body of knowledge developed by Sigmund Freud and his followers, devoted to the study of human psychological functioning and behavior. It has three applications: 1) a method of investigation of the mind; 2) a systemized body of knowledge about human behavior; and 3) a method of treatment of psychological or emotional illness. Under the broad umbrella of psychoanalysis there are at least 20 different theoretical orientations regarding the underlying theory of understanding of human mentation and human development. The various approaches in treatment called "psychoanalytic" vary as much as the different theories do. In addition, the term refers to a method of studying child development.

Freudian psychoanalysis refers to a specific type of treatment in which the "analysand" (analytic patient) verbalizes thoughts, including free associations, fantasies, and dreams, from which the analyst formulates the unconscious conflict causing the patient's symptoms and character problems, and interprets them for the patient to create insight for resolution of the problems.

The specifics of the analyst's interventions typically include confronting and clarifying the patient's pathological defenses, wishes, and guilt. Through the analysis of conflicts, including those contributing to resistance and that involving transference onto the analyst of distorted reactions, psychoanalytic treatment can clarify how patients unconsciously are their own worst enemies: how unconscious, symbolic reactions that have been stimulated by experience are causing symptoms. There are some classic psychoanalytic theories:

1) Topographic theory 
The theory posits that the mental apparatus can be divided in to the systems Conscious, Pre-conscious, and Unconscious. These systems are not anatomical structures of the brain but, rather, mental processes.

2) Structural Theory

This theory breaks the mind up into the id, the ego, and the superego. The ego was composed of those forces that opposed the drives-defensive operation. The superego was Freud's term for the conscience-values and ideals, shame and guilt. Freud here realized that drives could be conscious, and that consciousness vs unconsciousness was a quality of any mental operation or any mental conflict. Forgetting things could be done on purpose, or not. People could be aware of guilt, or not aware.

3) Ego psychology

The theory was refined by Hartmann, Loewenstein, and Kris books from 1939 though the late 1960s. Hartmann pointed out that there may be delays or deficits in many functions such as sensory perception, motor control, symbolic thought, logical thought, speech, abstraction, integration (synthesis), orientation, concentration, judgment about danger, reality testing, adaptive ability, executive decision - making, hygiene, and self-preservation.

4) Conflict Theory

This is an update and revision of structural theory that does away with some of the more arcane features of structural theory. Conflict theory looks at how emotional symptoms and character traits are complex solutions to intrapsychic conflict. A major goal of modern conflict theorist analysts is to attempt to change the balance of conflict through making aspects of the less adaptive solutions conscious so that they can be rethought, and more adaptive solutions found.

5) Object relations theory

The study explains vicissitudes of human relationships though a study of how internal representations of self and of others are structured. The problems include disturbances in an individual's capacity to feel 
warmth, empathy, trust, sense of security, identity stability, consistent emotional closeness, and stability in a relationships with chosen other human beings.

6) Relational psychoanalysis

Relational psychoanalysis emphasizes how the individual's personality is shaped by both real and imagined relationships with others, and how these relationship patterns are re-enacted in the interactions between analyst and patient.

7) Modern psychoanalysis

This is a body of theoretical and clinical knowledge extended Freud's theories to make them applicable to the full spectrum of emotional disorders.

\section{B. FINDING AND DISCUSSION}

\section{The Characters of Antony}

A once fierce and feared soldier who rules the Roman Empire along with Octavius Caesar and Lepidus, Antony, is one of the triumvirate. As the first act and scene, Antony has neglected his duties to Roman Empire by sending off the messenger. Antony keeps teasing Cleopatra. $\mathrm{He}$ is really in love with the Egyptian Queen.

His loyalty is divided between the Western and Eastern worlds; he is torn between the sense of duty and the desire to seek pleasure, between reason and passion. While he feels the need to reaffirm the honor that has made him a celebrated Roman hero, he is also madly in love with Cleopatra. This makes him forget about his duty in Egypt and become ignorant. The rumor about his affair with the Egyptian Queen has spread out in Roman Empire and makes him lose his honor.

Antony can be classified into a dynamic character because of his changing in behavior and character. His behavior and character change a lot in many scenes. Antony has so many sides, full of vitality and vigor. He is also a masque and a reveler. The changes appear when in the first scene, Antony grapples his love for Cleopatra and his duties to the Roman 
Empire. He talks about how deep his love is in a conversation about nature and measures their love, dismisses the duties by sending off the messenger and says that Cleopatra is the most important thing for him rather than Rome. However, in the next scene, he quickly changes his mind. He gets worried about his reputation and blames Cleopatra for all.

Another classification that should be noted is that Antony is also a round character, which is described in detail and complex during the dramatic conflict in his life.

Antony is also a melancholic and often makes reckless decisions. His passion becomes his consecutive character, his notorious pleasure are random and disconnected dissipations without the coherence of single aim. It can be seen that throughout the play he always teases Cleopatra and expresses his love to Cleopatra but he realizes his duty and honor in Rome. These are some dialogues that show Antony's characters:

1) There's beggary in the love that can be reckon'd. (I.i.16)

2) Then must thou needs find out new heaven, new earth. (I.i.18)

3) Let Rome in Tiber melt, and the wide arch / Of the ranged empire fall (I.i.35-36)

The dialogues above are Antony's dialogues before he receives messages from Rome. He tries to show his love to Cleopatra.

a. She is cunning past man's thought. (I.ii.124)

b. Would I had never seen her. (I.ii.130)

In the dialogue above, Antony quickly changes his minds after he receives the news from Rome. He blames the Egyptian Queen for his actions, abandoning his duties to the Rome. His actions, minds, and thoughts are like geographical poles. The best description to draw him in opposite directions represents the conflicts between his reasons and emotions, his duty and his pleasure, and his obligation and his private needs.

The last characterization is that Antony is an egotistical and personal person that he always spends his time for his own pleasure and spends relative little time to think about the Roman Empire. He uses a little 
time and a little of role as one of the Triumvirate. However, in several scenes, he shows that he is a benevolent general. That makes him possible to be categorized as a dynamic character.

\section{The Conflicts of Antony}

The very first conflict is when Antony enters one of the rooms of Cleopatra's palace along with Cleopatra party. Demetrius and Philo are discussing about Antony who has changed in many ways because of his love affair with Cleopatra. In their dialogue, it can be seen that the rumor of Antony and Cleopatra love affair has spread in Rome.

\section{PHILO}

Nay, but this dotage of our general's

O'erflows the measure: those his goodly eyes,

That o'er the files and musters of the war

Have glow'd like plated Mars, now bend, now turn,

The office and devotion of their view

Upon a tawny front: his captain's heart,

Which in the scuffles of great fights hath burst

The buckles on his breast, reneges all temper,

And is become the bellows and the fan

To cool a gipsy's lust.

Flourish. Enter ANTONY, CLEOPATRA, her Ladies, the Train, with Eunuchs fanning her

Look, where they come:

Take but good note, and you shall see in him.

The triple pillar of the world transform'd

Into a strumpet's fool: behold and see.

\section{DEMETRIUS}

Is Caesar with Antonius prized so slight?

PHILO 
Sir, sometimes, when he is not Antony,

He comes too short of that great property

Which still should go with Antony.

\section{DEMETRIUS}

I am full sorry

That he approves the common liar, who

Thus speaks of him at Rome: but I will hope

Of better deeds to-morrow. Rest you happy!

(Act 1 Scene 1)

Antony then faces the truth that he must take the responsible of the loss of Roman Empire in war against Pompey and his wife Fulvia has fought against his own Roman Empire, joining Pompey parties to defeat and taking control of Roman Empire. He regrets his action at the very first scene in act I where he teases and shows his love to Cleopatra.

In addition, when he hears that Fulvia has passed away because of sickness, it makes him more upset and feels guilty. It can be seen in the soliloquy of Antony, he regrets his affair with Cleopatra and forgetting Fulvia. Antony is concerned about the cause of the death of Fulvia and other things that he has neglected because of Cleopatra.

\section{MARK ANTONY}

Forbear me.

\section{Exit Second Messenger}

There's a great spirit gone! Thus did I desire it:

What our contempt doth often hurl from us,

We wish it ours again; the present pleasure,

By revolution lowering, does become

The opposite of itself: she's good, being gone;

The hand could pluck her back that shoved her on.

I must from this enchanting queen break off: 
Ten thousand harms, more than the ills I know, My idleness doth hatch. How now! Enobarbus!

(Act 1 Scene 2)

Antony is on his way from Egypt back to Rome, while Octavius Caesar is planning to defeat and take Antony's part of the triumvirate. Octavius Caesar feels that Antony has neglected his duty and thinks that the loss of the Roman Empire in a war with Pompei is part of his mistake. This is another conflict that Antony has. This is man versus man conflict between Antony and Octavius Caesar.

\section{The Finding of Antony's Borderline Personality Disorder}

The play opens in Alexandria, in one of the Cleopatra's palace rooms. As the play begins, two of Antony's friends are discussing about Antony's actions, the way he treats Cleopatra. His increasing fondness to Cleopatra makes him look fool and forget his duty. He only seeks of pleasure.

\section{PHILO}

Nay, but this dotage of our general's

O'erflows the measure: those his goodly eyes,

That o'er the files and musters of the war

Have glow'd like plated Mars, now bend, now turn,

The office and devotion of their view

Upon a tawny front: his captain's heart,

Which in the scuffles of great fights hath burst

The buckles on his breast, reneges all temper,

And is become the bellows and the fan

To cool a gipsy's lust.

Flourish. Enter ANTONY, CLEOPATRA, her Ladies, the Train, with Eunuchs fanning her 
Look, where they come:

Take but good note, and you shall see in him.

The triple pillar of the world transform'd

Into a strumpet's fool: behold and see.

\section{PHILO}

Sir, sometimes, when he is not Antony, He comes too short of that great property

Which still should go with Antony.

\section{DEMETRIUS}

I am full sorry

That he approves the common liar, who

Thus speaks of him at Rome: but I will hope

Of better deeds to-morrow. Rest you happy!

(Act 1

Scene 1)

As they ponder their general's unreasonable behavior, Antony and Cleopatra's party enters the room. Philo is afraid that all this beauty and pomp will make Antony become an addled lover who once was a fearful warrior of Roman Empire. In the conversation of Philo and Demetrius, it can be seen that Antony has changed in many ways. His behavior indicates that he has indeed let himselfbecome seduced by Cleopatra's sensuality and charm. As Antony and Cleopatra talk, both of them show their feeling each other by exaggerating their language.

\section{CLEOPATRA}

If it be love indeed, tell me how much.

\section{MARK ANTONY}

There's beggary in the love that can be reckon'd.

\section{CLEOPATRA}

I'll set a bourn how far to be beloved. 


\section{MARK ANTONY}

Then must thou needs find out new heaven, new earth.

\section{MARK ANTONY}

Let Rome in Tiber melt, and the wide arch

Of the ranged empire fall! Here is my space.

Kingdoms are clay: our dungy earth alike

Feeds beast as man: the nobleness of life

Is to do thus; when such a mutual pair

(Act 1 Scene 1)

Cleopatra teases Antony that since he has been unfaithful to his wife, it is quietly that he might not be faithful to Cleopatra too. As the messenger enters the room, Antony casts out the messenger without any intensions to know what the message from Rome is. It can be analyzed that Antony really does not care about what has happened in Rome. But in the next scene, once he gets the news from Rome, he suddenly changes his thoughts and behaviors.

\section{CONCLUSIONS}

Several symptoms and evidences of Antony's Borderline Personality Disorder can be found. The evidences that Antony has Borderline Personality Disorder are found in the acts and scenes. Antony's behaviors are like the symptoms such as problems with regulating emotions and thoughts, impulsive and reckless behavior, and unstable relationships with other people prove that Antony suffered from Borderline Personality disorder.

Those manifestations happen in Antony's life with some complexion and a little difference from the usual manifestation of Borderline personality disorder. Those manifestations can be considered as the evidence of Antony's Borderline Personality Disorder. They are: (1) Antony is a very romantic person and shows his love to Cleopatra. He tends to be very open when speaking about feelings and 
romance and he will often proclaim his love early on in a relationship.; (2) Antony feels depressed due to his self-image and his duties and his pleasure; He often experiences mood swings frequently within hours. From being narcissistic and arrogant to being depressed or angry and back to confident again within hours; (3) Antony is a love addict, he loves Cleopatra while he is still Fulvia's husband and after Fulvia's death; He is married with Octavia; (4) Antony is very jealous to Cleopatra, it can be seen when Thidias kisses Cleopatra's hand and Antony asks his guard to whip Thidias and they argue about it; (5) Antony chases Cleopatra's ships and his reckless and impulsive acts, leaving his army ruined and lose in the battlefield; AND (6) Antony feels desperate when he loses his war because he chased Cleopatra's ships. He feels so ashamed and wants to suicide by asking Eros to kill him but then he takes his own life by learning what Eros had done.

Antony shows that he fulfills some the Borderline personality disorder by showing his acts, behaviors, and thoughts toward every character and situation. However, even Antony does not fulfill all the symptoms and signs of the Borderline personality disorder, he still has the same ideas and views as the person who severe Borderline personality disorder. It can be concluded that Antony truly suffers from Borderline Personality Disorder by the evidences found in this analysis.

\section{BIBLIOGRAPHY}

Aristotles Six Elements of Drama. Retrieved July, 132014 from http://www.kyshakes.org/Resources/Aristotle.html

Carter, Ronald and John Mcrae. 1997. The Routledge History of Literature in

English. TJ International Ltd.: Padstow Cornwell

Character. Retrieved July 26, 2014, from

http://www.bedfordsmartins.com/literature/bedlit/glossary.htm

Cuddon, J. A. 1998. A Dictionary of Literary Terms and Literary Theory. Blackwell Publishers Ltd. 
Definition from Dictionary.com. Retrieved March 21, 2014, from

http://dictionary.reference.com/browse/satire

Dictionary.com, Drama. Retrieved April 3, 2014, from

http://dictionary.reference.com/browse/drama

Editorial Staff of Meriam - Webster.1993.Merriam - Webster Collegiate

Dictionary.Massachusets: Merriam - Webster Incorporate.

Elements of Drama. Retrieved July, 132014 from

http://www.indinetzone.com/2/elements drama.htm

Reiss, Timothy J.1992. The Meaning of Literature.Comell University Press.

Hornby, A.S. 1974. Oxford Advanced Learners Dictionary of Current English

(Revised Edition).

Oxford : Oxford University Press

Literature- A Research and Reference Guide.Retrieved July 132014 from

http://www.csustan.edu/english/reuben/pal/append/axh.html

Merriam - Webster Online Dictionary, Drama. Retrieved April 3, 2014, from

http://www.merriam

webster.com/dictionary/drama

Origin of Comedy.Retrieved March 21, 2014, from

http://www.thetrehistory.com/ancient/bates001.html.

Reuben, Paul P. PAL: Appendix H: Elements of Drama. PAL: Perspectives in American 